\title{
Diversification Strategy and Stock Price Crash Risk: Evidence from China
}

\author{
Jun $\mathrm{Qi}^{1} \&$ Wenying Diao \\ ${ }^{1}$ Management School, Jinan University, Guangzhou, China \\ Correspondence: Wenying Diao, Management School, Jinan University, Guangzhou, P.R. China. E-mail: \\ dwy1234jy@163.com
}

Received: January 24, 2020

Accepted: February 20, 2020

Online Published: February 24, 2020

doi:10.5539/ijbm.v15n3p94

URL: https://doi.org/10.5539/ijbm.v15n3p94

\begin{abstract}
This study examines the impact of the corporate diversification strategy on the stock price crash risk. Using a large sample of Chinese A-share listed companies for the period 2003-2017, we find the stock price crash risk significantly increases when the operation strategy of a firm changes from a specialized operation to a diversified operation or the degree of diversified operations deepens. We also find that our results are stronger for non-state-owned listed firms, but not significant for state-owned firms. Furthermore, we find that the significant positive association between diversification and crash risk is more pronounced for firms with low external audit quality and low analyst coverage. Our study suggests that the diversification of operating strategy matter in determine stock price crash risk.
\end{abstract}

Keywords: diversified operations, stock price crash risk, ownership structure, external audit quality, analyst coverage, Chinese stock market

\section{Introduction}

As one of the most important financial markets in the world, Chinese stock market experiences dramatic growth, showing great research value for both domestic and international scholars. Preventing the crash of stock prices and guaranteeing the steady of the capital market have become a significant issue when the strong supervision of financial risk becomes a consensus. However, in the most recent years, many well-known listed companies suffered stock price crashes. For example, HNA, Kangmei Pharmaceutical, LETV, Jindun and other companies. We observed that most of those suffering the stock price collapse are diversified companies, and even some of them are the more successful early diversified companies. The main purpose of this paper is to investigate two questions below: Have the stock prices of these companies plummeted due to diversification? What impact does diversification have on the stock price crash risk?

Stock price crash risk has received considerable attentions in the financial academic field since the outbreak of 2008 financial crisis, a large number of studies argue that the one critical factor that causes the crash risk is the inside managers tent to keep back the bad news for an extended period of time (i.e., Jin \& Myers,2006; Hutton et al., 2009). The bad news hoarding behave is like wrap fire in paper and when the accumulated bad news sudden release or disclose to the investors, which lead to the stock price to fall sharply, eventually causing the crash risk, as a negative return outlier. For diversified firms, due to its nature of multiple business units and complex structure levels, the flow of information and the timeliness of disclosure are significantly different from those of specialized operating company (Gong \&Huang, 2014). The more opaque the firm, the greater the amount of hidden, firm-specific bad news that may arrive in a given span of time. So we contend that in a diversified firm increase the information opaqueness which leads to the "natural accumulation" of bad news. Furthermore, it also increases the degree of information asymmetry and provides managers with the motivation and opportunities to withhold bad news and implement cover-up behavior. In this view, we employ the diversification strategy of listed firms in China stock market and link it with crash risk to examine whether the diversified strategy have a certain impact on stock price crash risk. In addition, we investigate the diversified company from a dynamic perspective. As a business strategy, diversification refers to a state in which an enterprise's business is distributed across multiple industries. From a dynamic perspective, diversification refers to an act of a strategic shift from specialization to diversification or entering a new industry (Zhang \& Zeng, 2010). So we adopted the combination of the time point horizontal comparison method and time period vertical comparison method to 
study different impact.

Our findings support our hypotheses. First, our results suggest that diversification strategy increases Chinese listed company's stock price crash risk. Furthermore, we find that stock price crash risk is significant increased when companies change from specialized operations to diversified operations or the degree of diversified operations increases. Considering the special existence of China's market ownership structure system, our results are stronger for non-SOEs, but not significant for SOEs. Finally, we find that strong external monitoring mitigates the impact of diversification strategy on crash risk. More specifically, we find that Big Four auditors and high analyst coverage help lessen the impact.

Our study makes several important contributions. First, we extend the literature on diversification strategy to include a firm's crash risk exposure. A large amount of literature on the factors affecting stock price crash risks, which can be roughly divided into analysis from inside and outside the enterprise: the internal factors include whether the executives are overconfident, and insider selling, Tax evasion, etc.(Kim et al.,2016; Wu \& Li, 2015; Kim et al., 2011a), and external factors include institutional investors, media supervision, social trust, social responsibility, etc. (Xu et al., 2013; Luo \& Du, 2014; Li et al., 2016; Quan et al., 2015). However, as a ubiquitous form of corporate development, diversified operations have an important impact on the timeliness and disclosure of information discovery, and stock price crash risks is mostly due to the sudden outbreak of accumulated bad news due to asymmetric information. Therefore, it is necessary to study the relationship between them. Based on previous research, this paper explores the impact of diversification strategy and the degree of diversification on stock price crash risks, and provides a reference for subsequent research on the consequences of diversified business. Moreover, different with prior studies, our paper conducted both horizontal analysis and vertical analysis to stress the impact of a strategy shift on the crash risk, implying that a specialized firm change to diversified firm or a diversified firm keep deepening the level of diversification increase the crash risk. Specially, our results demonstrate strong impact of diversification strategy and validates the impact of the degree of diversification on stock price crash risks under different external supervision, which can provide some basis for other scholars' subsequent research.

The rest of this paper is organized as follows. Section 2 presents theoretical review and develops hypothesis. Section 3 discusses sample, variables, and model. Section 4 reports the empirical results and Section 5 concludes the paper.

\section{Theoretical Background and Hypothesis Development}

At present, the most important views on the formation mechanism of the stock price crash risk rely on the "information hiding hypothesis" proposed by Jin and Myers (2006), and further some others papers analyze the impact of other factors inside and outside the company on this basis(Kim et al.,2011a;Wu,Zhanchi., \&Li,Xiaolong.,2015; Li et al., 2016). This paper will also revolve around this hypothesis, which is based on the agency theory and the information asymmetry theory, and believes that due to the existence of information asymmetry. That is, External Stakeholders can not timely and completely obtain relevant information about the operation of the enterprise, but Internal Managers can obtain the true operating status of the enterprise, which creates conditions for Internal Managers to conceal adverse news. At the same time, in order to satisfy their own interests, corporate managers often hide adverse news in the enterprise (Jin \& Myers, 2006). When bad news accumulate to a certain degree, or the company's relevant conditions no longer allow managers to continue to hide bad news, the bad news will break out, which will cause the stock price to fall sharply and cause the stock price crash. Subsequent papers also verified the hypothesis (Hutton et a1., 2009; Benmelech et a1., 2010).

\subsection{Diversification and Stock Price Crash Risk}

Diversified operation is a common management method adopted by modern firm. However, due to the complexity of its operation and related interest groups, it will not only cause information asymmetry, but also provide more opportunities and means to cover up bad news for managers, eventually triggering stock prices crash.

First, the complexity of diversification makes the company's information more difficult to understand externally, and increases the degree of information asymmetry (Dai \& Deng, 2008). Generally speaking, this kind of information asymmetry may come from two aspects. On the one hand, due to its many business units and complex structure levels, liquidity of information and timeliness of disclosure information are quite different from those of specialized companies (Gong,Guangming.\&Huang,Shiyin.,2014), this cumulative complexity increases the degree of information asymmetry; On the other hand, because its business units are more complex and the corresponding research costs are higher, compared with specialized companies, external researchers, such as analysts, may therefore conduct less detailed research on it (Cai \& Zeng, 2010), resulting in less 
information for External Investors and increasing information asymmetry.

Second, the complexity of diversified operations provides managers with more opportunities and means (Zhang $\& \mathrm{Li}, 2012$ ), making the behavior of hiding information more difficult to detect, and gives them more motivation to conceal bad news, which has led to stock price crash. This motivation may come from two aspects. On the one hand, the deepening of the degree of diversified operations may prevent managers from discovering and disclosing problems in a timely manner, prompting managers to unconsciously lead to the "natural accumulation" of bad news; On the other hand, when the company has bad news that may cause stock price volatility, managers are likely to conceal it based on various reasons such as performance incentives and profit intake to cover up the outflow of these messages (Jin \& Myers, 2006). Diversified operations usually have more business units or more affiliated companies than specialized operations. They provide managers with benefits and resources, and provide more convenience for resource exchange. The deeper degree of diversified operations, The more convenient of this kind behavior, the manager is likely to have a mind based on this, thinking that he has more opportunities to conduct more concealing behaviors, and then increases stock price crash risk. Accordingly, the following hypothesis is proposed:

H1: Diversification increases stock price crash risk.

However, the deepening of the degree of diversification mentioned above implies two states: one is a firm changes from a specialized operation to a diversified operation, and the other is the deepening of the degree of diversification of a diversified enterprise. Therefore, this paper will make assumptions according to the two states respectively to ensure the robustness of this paper (correspondingly, subsequent assumptions are the same).

H1a: Diversification strategy (that is, when the operation strategy of a firm changes from a specialized operation to a diversified operation) will increase stock price crash risk.

H1b: As the degree of diversified operations deepens, stock price crash risk will become greater.

\subsection{Ownership Structure, Diversification and Stock Price Crash Risk}

In China, there are still some differences between the state-owned firm and non-state-owned firm in terms of business operations, such as Entry barriers for specific industries (Telecommunications, Electricity, Railways, Energy, etc.), and the existence of Policy Industry monopolies, which has made non-state firm enter these industries still faces high barriers (Hu,Zuohao.,2018), which is largely affected by the institutional environment, however, it also shows that ownership structure determines the breadth and diversification of an enterprise's fields. At the same time, in the background of deepening reform, exploring the impact of ownership structure is also conducive to promoting fair competition in the market. Therefore, this paper divides the firm into state-owned firm and non-state-owned firm according to whether the ultimate controller is the government. Based on this, the full sample is grouped to further explore the impact of the degree of diversification on stock price crash risk.

First of all, for state-owned firm, the actual controller is the government. Compared with non-state-owned firm, the government has a stronger ability to manage the state of operation and information disclosure of state-owned firm (Tang \& Sun, 2014), and has lower operations risk, reducing the possibility of hiding bad news. In addition, because most state-owned enterprise executives have a political background, they value the status of "Political Person "(Wang, 2014). Enterprise management is only the basis for state-owned enterprise managers to seek political advancement, and political promotion is their more important career goal (Zheng et al., 2012), that is, state-owned enterprise executives value political interests more than economic interests (Yang,Ruilong.,2013), reducing motivation to hide bad news. Secondly, a considerable part of the industries covered by government-controlled firm are those related to the lifeblood of the state-owned economy, and are responsible for the development of capital markets and the promotion of state-owned enterprise reform. They are often subject to strict supervision by regulators such as the SASAC $(\mathrm{Li}, 2011)$. This also reduces the possibility of hiding bad news, thereby reducing stock price crash risk. Therefore, on the basis of Hypothesis 1, this paper predicts that after the full sample is divided into state-owned firm and non-state-owned firm, the positive effect of diversification on stock price crash risk may be mainly reflected in non-state-owned firm. Based on these arguments, we present our second hypothesis:

H2: compared with state-owned firm, the positive correlation between diversification and stock price crash risk is more significant in non-state-owned firm.

H2a: Compared with state-owned firm, the positive correlation between diversification strategy and stock price crash risk is more significant in non-state-owned firm. 
H2b: Compared with state-owned firm, the positive correlation between the degree of diversified operations and stock price crash risk is more significant in non-state-owned firm.

\subsection{Analyst Coverage, Diversification, and Stock Price Crash Risk}

Public announcements and financial disclosures of listed companies generally have a certain amount of information. Due to lack of professional capabilities and delays in receiving information, ordinary investors rarely capture such information in a timely manner, and it is difficult to have accurate understanding of this information. This situation increases the degree of information asymmetry to a certain extent. The participation of Analysts will make a big difference. On the one hand, analysts can analyze a company through long-term continuous attention, regular visits, etc. Through certain channels, they can even obtain more internal or private information about a company (Bradley et al.,2014); On the other hand, analysts have more professional analytical capabilities and higher professional sensitivity, and can use relevant knowledge such as Finance and Accounting to interpret the disclosed public information more accurately (Liu,2011). It will also reduce the degree of information asymmetry to a certain extent. Pan (2011) also found that Analysts in China are an effective extra-legal alternative mechanism. Their participation can reveal more company-specific information, reduce the opacity of company information, and timely release stock price crash risk. In other words, the presence of analysts has reduced the asymmetry of information, and also formed direct supervision of the company (Cang, 2008). For a company, the more analysts coverage, the more effectively investors can identify information, reduce the degree of information asymmetry, the greater the intensity of the company's supervision, and the less hidden bad information management will be. Thereby reducing stock price crash risk. These considerations lead to our next hypothesis:

H3: Compared with companies with a high degree of analyst coverage, in companies with a low degree of analyst coverage, there is a more significant positive correlation between diversification and stock price crash risk.

H3a: Compared with companies with a high degree of analyst coverage, in companies with a low degree of analyst coverage, there is a more significant positive correlation between diversification strategy and stock price crash risk.

H3b: Compared with companies with a high degree of analyst coverage, in companies with a low degree of analyst coverage, there is a more significant positive correlation between the degree of diversified operations and stock price crash risk.

\subsection{External Audit Quality, Diversification, and Stock Price Crash Risk}

External audit, as a third-party agency, plays the dual role of corporate governance, while acting as an information intermediary for companies and stakeholders. During the audit process, the accountant can use the necessary working conditions of the audit to access all relevant information of the company, determine whether there are major misstatements in the business process of the company, and issue the corresponding audit results. Therefore, managers will consciously reduce misconduct in order to avoid the adverse effects of negative audit results (Callen \& Fang,2017), which will affect stock price crash risk.

Generally speaking, the higher the quality of the external audit, the more it can provide protection for the authenticity and completeness of the company's information, while larger audit institutions have higher reputational losses and penalties due to their failure, which also need more costs in terms of staff training and audit time. As a result, they are more motivated and able to detect major errors in a company's financial information and identify managers' opportunistic behavior. It is generally believed that the size of the audit institution is a signal of its high quality (Jiang et al., 2016). The "Big Four" are considered to have higher audit quality. Previous studies have found that the transparency of accounting information of listed companies audited by the "Big Four" is significantly higher than that of non-Big4 audited listed companies (Wang \& Chen, 2006). In other words, high-quality external audits can constrain and timely discover the opportunistic behavior of managers concealing bad news, avoiding the accumulation of bad news, conveying real and effective information to the capital market so that stock prices accurately reflect the company's operating conditions and intrinsic value, thereby reducing the future stock price crash risk (Jiang et al., 2013).

Based on this, in the case of grouping external audit quality, this section verifies the relationship between diversification and stock price crash risk, and proposes the following hypotheses based on hypothesis 1:

H4: Compared with companies with high external audit quality, in companies with low external audit quality, there is a more significant positive correlation between diversification and stock price crash risk.

H4a: Compared with companies with high external audit quality, in companies with low external audit quality, 
there is a more significant positive correlation between diversification strategy and stock price crash risk.

H4b: Compared with companies with high external audit quality, in companies with low external audit quality, there is a more significant positive correlation between the degree of diversified operations and stock price crash risk.

\section{Sample, Variable Measurement, and Model Design}

\subsection{Data Sources and Sample}

Our initial sample consisted all A-share Chinese firms listed on Shanghai and Shenzhen stock exchanges during the period 2003-2018. Referring to the relevant literature on stock price crash risk (Xu, 2012), the dependent variable was treated with a lag period during the regression process. The final data is the relevant data from 2003 to 2017. We obtained the main operation data is taken from WIND database, other data from the China Stock Market and Accounting Research (CSMAR) database. We started our investigation from 2003 because of the availability of the corporate governance data on CSMAR database. Following prior studies (Hutton et al., 2009; Kim et al., 2011b), we select our sample using following criteria. First, we eliminated finance industry firms (e.g., Banks, Insurance companies, and Investment Trusts) due to different financial characteristics. Second, we dropped firm-year observations less than 30 trading weeks of stock returns data to precisely measure crash risk variables. Third, we dropped missing observations on control variables. Finally, The final sample yields 23,458 firm-year observations of 2,798 firms. At the same time, in order to avoid the impact of extreme values, this paper also performed winsorize processing on relevant data at the levels of $1 \%$ and $99 \%$.

\subsection{Variables Measurement}

\subsubsection{Measurement of Diversification Strategy}

This paper uses the segment report information disclosed in the annual reports of listed companies, and at the same time uses the "Industry Classification Guidelines for Listed Companies" issued by the China Securities Regulatory Commission in April 2001 as the standard to determine the industries involved. Then, in accordance with the "Accounting Standards for Business firm-Segment Reports" (Draft for Comment) issued by the Ministry of Finance in November 2001, The operation segments with sales income (or profit) accounting for more than $10 \%$ of the company's main operation income (or profit) are included in the reportable segments. $\mathrm{M}$ is the number of reportable segments for each listed company's industry as defined in this paper. If the number of industries involved in the company's main operation is equal to 1 , the dummy variable M_DUM $=0$, means that the company chooses to operate exclusively; if the number of industries is greater than $\overline{1}$, the dummy variable M_DUM $=1$, means that the company chooses to diversify (Zhang,Junsheng.\&Zeng,Yaminl.,2010). This paper also uses the criterion of excluding industries that account for less than $5 \%$ of the main operation income to determine the number of industries (M), and the analysis results are not affected.

\subsubsection{Measurement of Diversification Degree}

With reference to the processing method of Zhang and Deng (2010), this paper selects the entropy index to measure the degree of diversification of listed companies. The calculation formula is as follows:

$$
\mathrm{EI}=\sum P_{i} \operatorname{Ln}\left(1 / P_{i}\right)
$$

Where $P_{i}$ is the proportion of the listed company ${ }^{i}$ s main operation income in i industry to the total main business income of the year. This indicator is a positive indicator of the company's level of diversification. The higher the company's level of diversification, the greater value of EI; when the company is specialized, EI is 0 .

\subsubsection{Measures of Firm-Specific Crash Risk}

Following the prior literature (Jin and Myers, 2006; Hutton et al., 2009; Jiang \& Xu, 2015), we employ two firm-specific measures of stock price crash risk for each firm-year observation: 1. the negative coefficient of skewness of firm-specific daily returns (NCSKEW), 2. the down-to-up volatility of firm-specific daily returns (DUVOL).

To calculate firm-specific measures of stock price crash risk, we first estimate firm-specific residual daily returns from the following expanded market and industry index model regression for each firm and year (Hutton et al., 2009; Ye et al. 2015):

$$
r_{i, t}=\alpha_{0}+\alpha_{1} r_{m, t-2}+\alpha_{2} r_{m, t-1}+\alpha_{3} r_{m, t} \alpha_{4} r_{m, t+1}+\alpha_{5} r_{m, t+2}+\varepsilon_{i, t}
$$

Where $\mathrm{r}_{\mathrm{i}, \mathrm{t}}$ is the return on stock $\mathrm{i}$ in week $\mathrm{t}, \mathrm{r}_{\mathrm{m}, \mathrm{t}}$ is the return on the CSMAR value-weighted market index in week $t$, we define market adjusted rate of return $\mathrm{W}_{\mathrm{i}, \mathrm{t}}$ of stock $\mathrm{i}$ in the $\mathrm{t}$ week as firm-specific weekly return:

$$
W_{i, t}=\ln \left(1+\varepsilon_{i, t}\right)
$$


Our first firm-specific measure of stock price crash risk is the negative coefficient of skewness of firm-specific daily returns (NCSKEW), which constructed by the firm-specific weekly return. Thus, for any stock i over the fiscal year t.

$$
N C S K E W_{i, t}=-\left[n(n-1)^{3 / 2} \sum\left(W_{i, t}\right)^{3}\right] /\left[(n-1)(n-2)\left(\sum\left(W_{i, t}\right)^{2}\right)^{3 / 2}\right]
$$

where $\mathrm{n}$ is the number of observations of firm-specific daily returns during the fiscal year $\mathrm{t}$. The denominator is a normalization factor (Greene, 1993). This study adopts the convention that an increase in NCSKEW corresponds to a stock being more "crash prone", that is, having a more left-skewed distribution, hence the minus sign on the right-hand side of equation (4).

The second measure of firm-specific crash risk is called "down-to-up volatility" (DUVOL), calculated as follows:

$$
D U V O L_{i, t}=\ln \left\{\left[\left(n_{u p}-1\right) \sum_{\text {down }}\left(W_{i, t}\right)^{2}\right] /\left[\left(n_{\text {down }}-1\right) \sum_{u p}\left(W_{i, t}\right)^{2}\right]\right\}
$$

where $\mathrm{n}_{\text {up }}$ and $\mathrm{n}_{\text {down }}$ are the number of up and down days over the fiscal year $\mathrm{t}$, respectively. For any stock $\mathrm{i}$ over a one-year period, we separate the sample into "up" and "down" two group when firm-specific weekly returns above (below) the mean of the return. $\sum_{\text {down }}\left(W_{i, t}\right)^{2}$ means the sum of square $\mathrm{W}_{\mathrm{i}, \mathrm{t}}$ using the "down" group, and $\sum_{u p}\left(W_{i, t}\right)^{2}$ means the sum of square $\mathrm{W}_{\mathrm{i}, \mathrm{t}}$ using the "up" group. Similar to NCSKEW, a higher value of DUVOL corresponds to a stock being more "crash prone" (Callen, Jeffrey, \& Fang, 2015).

\subsubsection{Control Variables}

Following the prior literature (Kim et.a1.,2013;Xu Nianxing.,2013), we control for the following set of variables: Detrended turnover (OTURNOVER), Standard deviation (SIGMA), Stock returns (RET),Firm size (SIZE) (because large companies tend to diversify, we use the total asset logarithm (InSIZE) to control the size effect), Book to market ratio (BM), Leverage (LEVERAGE), return on assets (ROA).In addition, considering that stock price crash risk may have a lag effect, a negative return skew (NCSKEW) or the down-to-up volatility(DUVOL) of firm-specific daily returns is selected to control. It is shown in Table 1.

\begin{tabular}{|c|c|c|}
\hline Variables & Name & Definition \\
\hline Negative skewness & NCSKEW & $\begin{array}{l}\text { Negative return skew coefficient. The calculation method is shown in formula (4). If it lags } \\
\text { one period, it is NCSKEW } \\
i, t+1\end{array}$ \\
\hline Down-to-up volatility & DUVOL & $\begin{array}{l}\text { The ratio of the fluctuations in the returns is shown in formula (5). If it lags by one period, it } \\
\text { is DUVOL } i, t+1 \text {, and if it lags two periods, it is } \operatorname{DUVOL}_{i, t+2}\end{array}$ \\
\hline $\begin{array}{l}\text { Diversified operating } \\
\text { decisions }\end{array}$ & M_DUM & A dummy variable indicating if a firm is diversified operating, otherwise 0 \\
\hline Diversification degree & EI & Entropy index, calculation method see formula (1) \\
\hline State ownership & GOV & A dummy variable indicating if a firm is state-owned, otherwise 0 \\
\hline $\begin{array}{l}\text { External audit quality } \\
\text { dummy variable }\end{array}$ & Big4 & A dummy variable indicating if a firm is high audit quality, otherwise 0 \\
\hline Analyst coverage & Analyst1 & $\begin{array}{l}\text { A dummy variable indicating if a firm is high Analyst coverage, otherwise } 0 \text {, the calculation } \\
\text { method is described in the text. }\end{array}$ \\
\hline Detrended turnover & OTURNOVER & It is measured as the difference of mean monthly share turnover of year $\mathrm{t}$ and year $\mathrm{t}-1$. \\
\hline Standard deviation & SIGMA & Standard deviation of weekly stock returns during year. \\
\hline Stock returns & RET & Average weekly stock returns during year. \\
\hline Firm size & SIZE & Natural logarithm of total assets. \\
\hline Book to market ratio & $\mathrm{BM}$ & Book value of equity divided by market value of equity \\
\hline Leverage & LEVERAGE & Total liabilities divided by total assets. \\
\hline Return on assets & ROA & Income before extraordinary items divided by total assets. \\
\hline
\end{tabular}

Table 1. Variable definition table 


\subsection{Model Design}

Diversification as a operation strategy, on the one hand, refers to a state in which an enterprise's operation is spread across multiple industries; on the other hand, diversification also refers to an act of entering a new industry. Therefore, only static and dynamic comprehensive research can accurately reflect the effect of diversification on stock price crash risk. Based on this, the analysis of the effect of diversified operations on stock price crash risk mainly starts from the following two methods: First, comparing the crash risk of diversified operating companies and specialized operating companies from a horizontal perspective; Second, comparing the effect of diversification deepen on crash risk from a vertical perspective. It is embodied in the comprehensive effect of horizontal comparison and vertical comparison through adding the fixed effect of firm or not (Zeng \& Zhang, 2010). Without the fixed effect of the enterprise, all the cross-section data and time series data in the panel data are treated as independent individuals, and all the relationships between $\mathrm{x}$ and $\mathrm{y}$ are represented by a straight line. At this time, the change of $\mathrm{x}$ is caused by the individual change in the sense of cross section, and the change of $\mathrm{y}$ is called the lateral effect of $\mathrm{x}$. After adding the firm fixed effect, each individual $\mathrm{x}$ and $\mathrm{y}$ have a straight line, the slope of each line is same, but the intercept is different. At this time, the change in $\mathrm{x}$ is no longer an individual change, but a change in $\mathrm{x}$ of an individual in the time series. The resulting change in $y$ is called the vertical effect of $x$.

Specifically, when analyzing the relationship between a company's diversification strategy and stock price crash risk, that is, the impact of a company's choice of diversified or specialized operations or a company changes from a specialized operation to a diversified operation on stock price crash risk, this paper mainly uses the following model:

$$
\begin{aligned}
\operatorname{NCSKEW~}_{\mathrm{i}, \mathrm{t}+1} & =\alpha+\beta \times \mathrm{M}_{-} \mathrm{DUM}_{\mathrm{i}, \mathrm{t}}+\gamma \times \text { Controls }_{\mathrm{i}, \mathrm{t}}+\varepsilon_{\mathrm{i}} \\
\operatorname{DUVOL}_{\mathrm{i}, \mathrm{t}+1} & =\alpha+\beta \times \mathrm{M}_{-} \mathrm{DUMM}_{\mathrm{i}, \mathrm{t}}+\gamma \times \text { Controls }_{\mathrm{i}, \mathrm{t}}+\varepsilon_{\mathrm{i}}
\end{aligned}
$$

To analyze the relationship between the degree of diversification and stock price crash risk, that is, to study the impact on stock price crash risk when the degree of diversification is deepen, the following model is used:

$$
\begin{aligned}
& \operatorname{NCSKEW~}_{\mathrm{i}, \mathrm{t}+1}=\alpha+\beta \times \mathrm{EI}_{\mathrm{i}, \mathrm{t}}+\gamma \times \text { Controls }_{\mathrm{i}, \mathrm{t}}+\varepsilon_{\mathrm{i}} \\
& \operatorname{DUVOL}_{\mathrm{i}, \mathrm{t}+1}=\alpha+\beta \times \mathrm{EI}_{\mathrm{i}, \mathrm{t}}+\gamma \times \text { Controls }_{\mathrm{i}, \mathrm{t}}+\varepsilon_{\mathrm{i}}
\end{aligned}
$$

In the above four models, we will perform regression by adding general constant terms or fixed effects to verify the horizontal or vertical effects. Our focus is on the effect of diverfication on future stock price crash risk, that is, on the coefficient $\beta$. To dig out how the ownership structure influence the correlation between the relationship of enterprises and stock price crash risk, this paper divides the enterprise groups into state-owned and non-state-owned groups, and contrast coefficient difference. Similarly, in order to tap the impact of external oversight, we have also selected two indicators, analyst coverage and external audit quality, and have similar treatments.

\section{Empirical Results}

\subsection{Descriptive Statistics}

Table 2. Descriptive statistics

\begin{tabular}{llllll}
\hline VARIABLES & $\mathrm{N}$ & MEAN & SD & MIN & MAX \\
\hline NCSKEW $_{\mathrm{i}, \mathrm{t}+1}$ & 22835 & -0.256 & 0.692 & -2.283 & 1.685 \\
DUVOL $_{\mathrm{i}, \mathrm{t}+1}$ & 22835 & -0.165 & 0.337 & -0.965 & 0.720 \\
EI & 23458 & 0.305 & 0.376 & 0 & 1.310 \\
$\mathrm{M}_{-}$DUM & 23458 & 0.414 & 0.493 & 0 & 1 \\
NCSKEW $_{\mathrm{i}, \mathrm{t}}$ & 23458 & -0.241 & 0.679 & -2.268 & 1.605 \\
DUVOL $_{\mathrm{i}, \mathrm{t}}$ & 23458 & -0.158 & 0.334 & -0.96 & 0.711 \\
RET & 23458 & -0.001 & 0.001 & -0.006 & 0 \\
SIGMA & 23458 & 0.049 & 0.019 & 0.017 & 0.113 \\
OTURNVOER & 23100 & -0.085 & 0.436 & -1.74 & 0.928 \\
BM & 23458 & 0.534 & 0.252 & 0.083 & 1.100 \\
LEVERAGE & 23458 & 0.461 & 0.217 & 0.05 & 1.148 \\
ROA & 23456 & 0.04 & 0.06 & -0.223 & 0.231 \\
SIZE & 23458 & 21.88 & 1.269 & 19.06 & 25.66 \\
\hline
\end{tabular}


Table 2 reports descriptive statistics. The mean value of the stock price crash risk indicators NCSKEW $_{i, t+1}$ and DUVOL $_{i, t+1}$ are -0.256 and -0.165 , indicating that there is a large difference in the stock price crash risk in China, which is basically consistent with prior studies(Jiang et al.,2015;Jebran et al.,2019; Xu et al.,2014). In terms of diversification indicator, the mean value of EI is 0.305 . The minimum and maximum differences are large, indicating that Chinese listed companies have a low business diversification level, but the diversification behavior is growing year by year, and there are large differences among firms. Further, the statistics of control variables are consistent with Chinese researches. (Pan,Yue.,2013;Jiang,Xuanyu. ,2011)

\subsection{Analysis of Empirical Results}

\subsubsection{Diversification Strategy and Stock Price Crash Risk}

This paper examines the impact of diversification strategy on stock price crash risk using diversified operating dummy variables. This section includes four regression models: the dependent variables of the first and second regression models are negative return skewness $\operatorname{NCSKEW}_{i, t+1}$, the third and fourth dependent variables are the down-to-up volatility of firm-specific daily returns DUVOL $_{i, t+1}$; the first and third models add general constant terms, no fixed effects of the enterprise, and focus on the horizontal effect of diversified operations; the second and fourth models include firm fixed effects in order to examine the vertical effects of diversified operations over time.

Table 3. Diversification strategy and stock price crash risk

\begin{tabular}{|c|c|c|c|c|}
\hline \multirow{2}{*}{ VARIABLES } & \multicolumn{2}{|c|}{ NCSKEW $_{\mathrm{i}, t+1}$} & \multicolumn{2}{|c|}{ DUVOL $_{i, t+1}$} \\
\hline & (1) & (2) & (3) & (4) \\
\hline \multirow[t]{2}{*}{ M_DUM } & -0.00377 & $0.0440^{* * *}$ & -0.000545 & $0.0247 * * *$ \\
\hline & $(0.00935)$ & $(0.0158)$ & $(0.00455)$ & $(0.00772)$ \\
\hline \multirow[t]{2}{*}{$\operatorname{NCSKEW}_{\mathrm{i}, \mathrm{t}}$} & $0.0374 * * *$ & $-0.0824 * * *$ & & \\
\hline & $(0.00698)$ & $(0.00711)$ & & \\
\hline \multirow[t]{2}{*}{ DUVOL $_{i, t}$} & & & $0.0345 * * *$ & $-0.0828 * * *$ \\
\hline & & & $(0.00687)$ & $(0.00694)$ \\
\hline \multirow[t]{2}{*}{ RET } & $40.75^{* *}$ & 21.71 & 3.587 & -6.401 \\
\hline & $(17.85)$ & (19.01) & (8.634) & $(9.348)$ \\
\hline \multirow[t]{2}{*}{ SIGMA } & 0.880 & -0.683 & -0.816 & $-1.672 * * *$ \\
\hline & $(1.088)$ & (1.145) & $(0.524)$ & $(0.560)$ \\
\hline \multirow[t]{2}{*}{ OTURNOVER } & -0.0102 & 0.0142 & -0.00552 & 0.00639 \\
\hline & $(0.0109)$ & $(0.0125)$ & $(0.00534)$ & $(0.00616)$ \\
\hline \multirow[t]{2}{*}{ BM } & $-0.303 * * *$ & $-0.370 * * *$ & $-0.159 * * *$ & $-0.202 * * *$ \\
\hline & $(0.0240)$ & $(0.0328)$ & $(0.0119)$ & $(0.0160)$ \\
\hline \multirow[t]{2}{*}{ LEVERAGE } & $0.104 * * *$ & $0.112 * *$ & $0.0385^{* * *}$ & $0.0425^{*}$ \\
\hline & $(0.0258)$ & $(0.0495)$ & $(0.0126)$ & $(0.0240)$ \\
\hline \multirow[t]{2}{*}{ ROA } & $0.244 * * *$ & $0.224 *$ & $0.0793 *$ & 0.0789 \\
\hline & $(0.0922)$ & $(0.115)$ & $(0.0453)$ & $(0.0568)$ \\
\hline \multirow[t]{2}{*}{ SIZE } & $-0.0285^{* * *}$ & $-0.0368 * * *$ & $-0.0118^{* * *}$ & $-0.0128 * * *$ \\
\hline & $(0.00456)$ & $(0.00853)$ & $(0.00224)$ & $(0.00411)$ \\
\hline \multirow[t]{2}{*}{ Constant } & $0.496^{* * *}$ & $0.716^{* * *}$ & $0.208^{* * *}$ & $0.251 * * *$ \\
\hline & $(0.102)$ & $(0.189)$ & $(0.0497)$ & $(0.0912)$ \\
\hline Fixed Effect & - & + & - & + \\
\hline Observations & 22481 & 22481 & 22481 & 22481 \\
\hline $\mathrm{R} 2$ & 0.0195 & 0.0153 & 0.0191 & 0.0167 \\
\hline
\end{tabular}

Note. The $\mathrm{t}$ value in parentheses; $* * *$ means significant at $1 \%$ level, ** means significant at $5 \%$ level, * means significant at $10 \%$ level.

Table 3 shows the results of our regression analysis of equation (6) and equation (7). Across all four models, there is no relations in columns 1 and 3, the estimated coefficients for M_DUM are positive and significant at $1 \%$ level in columns 2 and 4. The results indicate that from the horizontal point of view, there is no difference in stock price crash risk between a diversified operations and a specialized opeartions. However,from a horizontal perspective, for a firm, as it changes from specialized operations to diversified operations, its stock price crash risk increases, which is in line with H1a expectations. 


\subsubsection{Degree of Diversified Operations and Stock Price Crash Risk}

This section examines the impact of the degree of diversified operations on stock price crash risk, and uses the EI (Entropy Index) to measure the degree of diversified operations, and analyzes the relationship between the degree of diversified operations and stock price crash risk to verify the hypothesis H1b.

Table 4. Degree of diversified operations and stock price crash risk

\begin{tabular}{|c|c|c|c|c|}
\hline \multirow{2}{*}{ VARIABLES } & \multicolumn{2}{|c|}{$\operatorname{NCSKEW}_{\mathrm{i},+1}$} & \multicolumn{2}{|c|}{ DUVOL $_{i, t+1}$} \\
\hline & (1) & $(2)$ & (3) & (4) \\
\hline \multirow[t]{2}{*}{ EI } & -0.0142 & $0.0737 * * *$ & -0.00539 & $0.0415^{* * *}$ \\
\hline & $(0.0124)$ & $(0.0229)$ & $(0.00601)$ & $(0.0111)$ \\
\hline \multirow[t]{2}{*}{$\operatorname{NCSKEW}_{\mathrm{i}, \mathrm{t}}$} & $0.0373 * * *$ & $-0.0825 * * *$ & & \\
\hline & $(0.00698)$ & $(0.00711)$ & & \\
\hline \multirow[t]{2}{*}{ DUVOL $_{i, t}$} & & & $0.0344 * * *$ & $-0.0829 * * *$ \\
\hline & & & $(0.00687)$ & $(0.00694)$ \\
\hline \multirow[t]{2}{*}{ RET } & $40.42 * *$ & 22.33 & 3.430 & -6.054 \\
\hline & $(17.85)$ & $(19.02)$ & $(8.635)$ & (9.348) \\
\hline \multirow[t]{2}{*}{ SIGMA } & 0.858 & -0.654 & -0.827 & $-1.656 * * *$ \\
\hline & $(1.088)$ & $(1.146)$ & $(0.524)$ & $(0.560)$ \\
\hline \multirow[t]{2}{*}{ OTURNOVER } & -0.00975 & 0.0141 & -0.00528 & 0.00631 \\
\hline & $(0.0109)$ & $(0.0125)$ & $(0.00534)$ & $(0.00616)$ \\
\hline \multirow[t]{2}{*}{ BM } & $-0.303 * * *$ & $-0.371 * * *$ & $-0.159 * * *$ & $-0.203 * * *$ \\
\hline & $(0.0240)$ & $(0.0328)$ & $(0.0119)$ & $(0.0160)$ \\
\hline \multirow[t]{2}{*}{ LEVERAGE } & $0.104 * * *$ & $0.111^{* *}$ & $0.0385 * * *$ & $0.0421^{*}$ \\
\hline & $(0.0258)$ & $(0.0496)$ & $(0.0126)$ & $(0.0240)$ \\
\hline \multirow[t]{2}{*}{ ROA } & $0.241 * * *$ & $0.224^{*}$ & $0.0780^{*}$ & 0.0792 \\
\hline & $(0.0922)$ & $(0.115)$ & $(0.0453)$ & $(0.0567)$ \\
\hline \multirow[t]{2}{*}{ SIZE } & $-0.0284 * * *$ & $-0.0377 * * *$ & $-0.0118 * * *$ & $-0.0133 * * *$ \\
\hline & $(0.00456)$ & $(0.00856)$ & $(0.00224)$ & $(0.00412)$ \\
\hline \multirow[t]{2}{*}{ Constant } & $0.496 * * *$ & $0.730 * * *$ & $0.208^{* * *}$ & $0.259 * * *$ \\
\hline & $(0.102)$ & $(0.190)$ & $(0.0497)$ & $(0.0914)$ \\
\hline Fixed Effect & - & + & - & + \\
\hline Observations & 22481 & 22481 & 22481 & 22481 \\
\hline R2 & 0.0195 & 0.0155 & 0.0191 & 0.0169 \\
\hline
\end{tabular}

Note. The $\mathrm{t}$ value in parentheses; $* *$ means significant at $1 \%$ level, ${ }^{* *}$ means significant at $5 \%$ level, ${ }^{*}$ means significant at $10 \%$ level.

Table 4 shows the results of our regression analysis of equation (8) and equation (9), where we measure future firm-specific crash risk by $\mathrm{NCSKEW}_{\mathrm{i}, \mathrm{t}+1}$ in columns 1 to 2 and by DUVOL $\mathrm{D}_{\mathrm{i},+1}$ in columns 3 to 4 , respectively. Across all four models, there is no relations in columns 1 and 3, the estimated coefficients for EI are positive and significant at $1 \%$ level in columns 2 and 4 . The results indicate that from the horizontal point of view, there is no difference in stock price crash risk between different degrees of diversified operations. However, from a horizontal perspective, for a firm, as its degree of diversified operations deepens, stock price crash risk increases, which is in line with $\mathrm{H} 1 \mathrm{~b}$ expectations. Thus verifying hypothesis 1: Diversification will increase stock price crash risk.

4.2.3 Ownership Structure, Diversification and Stock Price Crash Risk 
From the empirical results of 4.2.1 and 4.2.2, it can be seen that the impact of diversification on stock price crash risk is mainly reflected in the vertical effect. Therefore, the regression models in this section include firm fixed effects. Table 5 and Table 6 investigate the impact of diversification strategy and the degree of diversified operations on crash risk under dividing the enterprise groups into state-owned and non-state-owned groups.

Table 5. Ownership structure, diversification strategy and stock price crash risk

\begin{tabular}{|c|c|c|c|c|}
\hline \multirow[t]{2}{*}{ VARIABLES } & \multicolumn{2}{|c|}{$\operatorname{NCSKEW}_{\mathrm{i}, t+1}$} & \multicolumn{2}{|c|}{$\operatorname{DUVOL}_{\mathrm{i}, t+1}$} \\
\hline & $\mathrm{GOV}=1$ & $\mathrm{GOV}=0$ & $\mathrm{GOV}=1$ & $\mathrm{GOV}=0$ \\
\hline \multirow[t]{2}{*}{ M_DUM } & 0.00305 & $0.0745^{* * *}$ & 0.00526 & $0.0386^{* * *}$ \\
\hline & $(0.0228)$ & $(0.0227)$ & $(0.0112)$ & $(0.0111)$ \\
\hline \multirow[t]{2}{*}{$\operatorname{NCSKEW}_{\mathrm{i}, \mathrm{t}}$} & $-0.0733 * * *$ & $-0.113 * * *$ & & \\
\hline & $(0.00989)$ & $(0.0101)$ & & \\
\hline \multirow[t]{2}{*}{ DUVOL $_{\mathrm{i}, \mathrm{t}}$} & & & $-0.0763 * * *$ & $-0.110 * * *$ \\
\hline & & & $(0.00940)$ & $(0.00999)$ \\
\hline \multirow[t]{2}{*}{ RET } & -7.808 & 34.55 & -22.29 & 2.094 \\
\hline & $(29.03)$ & $(26.40)$ & (13.97) & (13.13) \\
\hline \multirow[t]{2}{*}{ SIGMA } & -1.615 & -0.236 & $-2.249 * * *$ & -1.298 \\
\hline & $(1.686)$ & $(1.671)$ & $(0.802)$ & $(0.829)$ \\
\hline \multirow[t]{2}{*}{ OTURNOVER } & 0.0329 & -0.00680 & 0.0131 & -0.00300 \\
\hline & $(0.0203)$ & $(0.0159)$ & $(0.00997)$ & $(0.00784)$ \\
\hline \multirow[t]{2}{*}{ BM } & $-0.390 * * *$ & $-0.346 * * *$ & $-0.210 * * *$ & $-0.197 * * *$ \\
\hline & $(0.0431)$ & $(0.0518)$ & $(0.0211)$ & $(0.0252)$ \\
\hline \multirow[t]{2}{*}{ LEVERAGE } & 0.0905 & $0.120^{*}$ & 0.0300 & 0.0514 \\
\hline & $(0.0769)$ & $(0.0691)$ & $(0.0374)$ & $(0.0333)$ \\
\hline \multirow[t]{2}{*}{ ROA } & $0.381 * *$ & 0.160 & $0.144 *$ & 0.0622 \\
\hline & $(0.171)$ & $(0.157)$ & $(0.0859)$ & $(0.0773)$ \\
\hline \multirow[t]{2}{*}{ SIZE } & $-0.0681 * * *$ & -0.00103 & $-0.0282 * * *$ & 0.00448 \\
\hline & $(0.0129)$ & $(0.0126)$ & $(0.00636)$ & $(0.00599)$ \\
\hline \multirow[t]{2}{*}{ Constant } & $1.430 * * *$ & -0.0684 & $0.606 * * *$ & -0.130 \\
\hline & $(0.287)$ & $(0.280)$ & $(0.141)$ & $(0.133)$ \\
\hline Fixed Effect & + & + & + & + \\
\hline Observations & 10902 & 11522 & 10902 & 11522 \\
\hline R2 & 0.0201 & 0.0180 & 0.0203 & 0.0200 \\
\hline
\end{tabular}

Note. The $\mathrm{t}$ value in parentheses; $* * *$ means significant at $1 \%$ level, ${ }^{* *}$ means significant at $5 \%$ level, $*$ means significant at $10 \%$ level.

Table 5 shows the two group regression results of model(6) and model(7). We divides the enterprise groups into state-owned $(\mathrm{GOV}=1)$ and non-state-owned $(\mathrm{GOV}=0)$ groups.In non-state-owned group,the coefficient of M_DUM is 0.0745 and 0.0386 , and it is significant at the level of $1 \%$, indicating that in non-state-owned firm, stock price crash risk significantly increases when the enterprise changes from a specialized operations to a diversified operations; In state-owned group, the coefficient of M_DUM is not significant. Suppose 2a is established. 
Table 6. Ownership structure, degree of diversified operations and stock price crash risk

\begin{tabular}{|c|c|c|c|c|}
\hline \multirow[t]{2}{*}{ VARIABLES } & \multicolumn{2}{|c|}{ NCSKEW $_{i, t+1}$} & \multicolumn{2}{|c|}{ DUVOL $_{i, t+1}$} \\
\hline & $\mathrm{GOV}=1$ & $\mathrm{GOV}=0$ & $\mathrm{GOV}=1$ & $\mathrm{GOV}=0$ \\
\hline \multirow[t]{2}{*}{ EI } & 0.0198 & $0.126^{* * *}$ & 0.0137 & $0.0676^{* * *}$ \\
\hline & $(0.0331)$ & $(0.0340)$ & $(0.0162)$ & $(0.0165)$ \\
\hline \multirow[t]{2}{*}{ NCSKEW $_{i, t}$} & $-0.0735 * * *$ & $-0.113 * * *$ & & \\
\hline & $(0.00988)$ & $(0.0101)$ & & \\
\hline \multirow[t]{2}{*}{ DUVOL $_{i, t}$} & & & $-0.0764 * * *$ & $-0.110^{* * *}$ \\
\hline & & & $(0.00939)$ & $(0.00999)$ \\
\hline \multirow[t]{2}{*}{ RET } & -7.743 & 35.66 & -22.26 & 2.736 \\
\hline & $(29.02)$ & (26.41) & (13.96) & (13.13) \\
\hline \multirow[t]{2}{*}{ SIGMA } & -1.616 & -0.178 & $-2.249 * * *$ & -1.264 \\
\hline & $(1.686)$ & $(1.672)$ & $(0.802)$ & $(0.829)$ \\
\hline \multirow[t]{2}{*}{ OTURNOVER } & 0.0328 & -0.00708 & 0.0130 & -0.00318 \\
\hline & $(0.0203)$ & $(0.0159)$ & $(0.00997)$ & $(0.00785)$ \\
\hline \multirow[t]{2}{*}{$\mathrm{BM}$} & $-0.391 * * *$ & $-0.346^{* * *}$ & $-0.210 * * *$ & $-0.197 * * *$ \\
\hline & $(0.0431)$ & $(0.0518)$ & $(0.0211)$ & $(0.0251)$ \\
\hline \multirow[t]{2}{*}{ LEVERAGE } & 0.0907 & $0.116^{*}$ & 0.0301 & 0.0487 \\
\hline & $(0.0770)$ & $(0.0694)$ & $(0.0374)$ & $(0.0335)$ \\
\hline \multirow[t]{2}{*}{ ROA } & $0.384 * *$ & 0.160 & $0.145^{*}$ & 0.0626 \\
\hline & $(0.171)$ & $(0.156)$ & $(0.0858)$ & $(0.0773)$ \\
\hline \multirow[t]{2}{*}{ SIZE } & $-0.0686 * * *$ & -0.00266 & $-0.0285 * * *$ & 0.00353 \\
\hline & $(0.0130)$ & $(0.0126)$ & $(0.00638)$ & $(0.00599)$ \\
\hline \multirow[t]{2}{*}{ Constant } & $1.436 * * *$ & -0.0391 & $0.609 * * *$ & -0.114 \\
\hline & $(0.287)$ & $(0.280)$ & $(0.141)$ & $(0.133)$ \\
\hline Fixed Effect & + & + & + & + \\
\hline Observations & 10902 & 11522 & 10902 & 11522 \\
\hline R2 & 0.0201 & 0.0184 & 0.0203 & 0.0206 \\
\hline
\end{tabular}

Note. The $\mathrm{t}$ value in parentheses; $* *$ means significant at $1 \%$ level, $* *$ means significant at $5 \%$ level, $*$ means significant at $10 \%$ level.

Table 6 shows the two group regression results of model (8) and model (9). In non-state-owned group, the coefficient of EI is 0.126 and 0.0676 , and it is significant at the level of $1 \%$, indicating that in non-state-owned firm, stock price crash risk significantly increases when the degree of diversified operations deepens ; In state-owned group, the coefficient of EI is not significant. Suppose $2 \mathrm{~b}$ is established.

In addition, from the results of Table 5 and Table 6 , we can see that the values of M_DUM and EI are significantly positive and larger than the full sample results. This validates $\mathrm{H} 2$ : Compared with state-owned firm, in non-state-owned firm, the positive correlation between diversification and stock price crash risk is more significant. The above results also show that Ownership structure of listed companies in China has an important impact on the relationship between diversification and stock price crash risk, confirming that the underlying institutional factors behind diversification are closely related to stock price crash risk.

\subsection{Further Analysis}

\subsubsection{Analyst Coverage, Diversification, and Stock Price Crash Risk}

In this section, we divide the full sample into two groups of high Analyst coverage and low Analyst coverage according to the degree of Analyst coverage. We use the number of analysts' tracking and research reports as variables to measure the degree of analyst coverage (Xie, 2017), and performs grouped regression on the full 
sample. Specifically, the definition of Analyst1 dummy variable for the analyst tracking. The calculation method is the number of tracked analysts $=\mathrm{Ln}$ (the number of analysts issuing earnings forecast reports +1 ), if the number of analysts 'tracking of a company is higher than the median number of analysts' tracking of all companies in the industry in this year, it will be divided into a group of high Analyst coverage, and Analyst1=1; otherwise, 0 .

Table 7. Analyst coverage, diversification strategy and stock price crash risk

\begin{tabular}{|c|c|c|c|c|}
\hline \multirow[t]{2}{*}{ VARIABLES } & \multicolumn{2}{|c|}{ NCSKEW $_{\mathrm{i}, t+1}$} & \multicolumn{2}{|c|}{ DUVOL $_{i, t+1}$} \\
\hline & Analyst $1=1$ & Analyst $1=0$ & Analyst $1=1$ & Analyst $1=0$ \\
\hline \multirow[t]{2}{*}{ M_DUM } & 0.0283 & $0.0630 * * *$ & 0.0147 & $0.0342 * * *$ \\
\hline & $(0.0259)$ & $(0.0214)$ & $(0.0129)$ & $(0.0103)$ \\
\hline \multirow[t]{2}{*}{ NCSKEW $_{\mathrm{i}, \mathrm{t}}$} & $-0.119 * * *$ & $-0.0941 * * *$ & & \\
\hline & $(0.0111)$ & $(0.00991)$ & & \\
\hline \multirow[t]{2}{*}{ DUVOL $_{i, t}$} & & & $-0.120 * * *$ & $-0.0921 * * *$ \\
\hline & & & $(0.0108)$ & $(0.00981)$ \\
\hline \multirow[t]{2}{*}{ RET } & 0.230 & 32.25 & -12.20 & -5.808 \\
\hline & $(30.59)$ & $(27.12)$ & (15.33) & (13.18) \\
\hline \multirow[t]{2}{*}{ SIGMA } & -2.401 & 0.219 & $-2.136 * *$ & $-1.564^{*}$ \\
\hline & $(1.827)$ & $(1.678)$ & $(0.911)$ & $(0.806)$ \\
\hline \multirow[t]{2}{*}{ OTURNOVER } & $-0.0384 *$ & $0.0357 * *$ & $-0.0209 * *$ & $0.0178^{* *}$ \\
\hline & $(0.0199)$ & $(0.0169)$ & $(0.0102)$ & $(0.00825)$ \\
\hline \multirow[t]{2}{*}{$\mathrm{BM}$} & $-0.506^{* * *}$ & $-0.289 * * *$ & $-0.255^{* * *}$ & $-0.172 * * *$ \\
\hline & $(0.0553)$ & $(0.0428)$ & $(0.0272)$ & $(0.0208)$ \\
\hline \multirow[t]{2}{*}{ LEVERAGE } & 0.133 & 0.0780 & 0.0360 & 0.0336 \\
\hline & $(0.0855)$ & $(0.0642)$ & $(0.0427)$ & $(0.0309)$ \\
\hline \multirow[t]{2}{*}{ ROA } & 0.334 & -0.0439 & 0.151 & -0.0466 \\
\hline & $(0.227)$ & $(0.143)$ & $(0.113)$ & $(0.0692)$ \\
\hline \multirow[t]{2}{*}{ SIZE } & $-0.0419 * * *$ & $-0.0307^{* *}$ & $-0.0142 * *$ & -0.00918 \\
\hline & $(0.0134)$ & $(0.0131)$ & $(0.00670)$ & $(0.00629)$ \\
\hline \multirow[t]{2}{*}{ Constant } & $0.975^{* * *}$ & $0.487^{*}$ & $0.335^{* *}$ & 0.141 \\
\hline & $(0.306)$ & $(0.283)$ & $(0.153)$ & $(0.136)$ \\
\hline Fixed Effect & + & + & + & + \\
\hline Observations & 10070 & 12411 & 10070 & 12411 \\
\hline $\mathrm{R} 2$ & 0.0275 & 0.0137 & 0.0278 & 0.0154 \\
\hline
\end{tabular}

Note. The $\mathrm{t}$ value in parentheses; *** means significant at $1 \%$ level, ${ }^{* *}$ means significant at $5 \%$ level, $*$ means significant at $10 \%$ level.

Table 7 shows the two group regression results of model (6) and model (7) when the grouping variable is the dummy variable Analyst 1 . In low degree of Analyst coverage (Analyst1 $=0$ ) group, the coefficient of M_DUM is 0.063 and 0.0342 , and it is significant at the level of $1 \%$, which shows that in companies with a low degree of Analyst coverage, stock price crash risk significantly increases when the enterprise changes from a specialized operations to a diversified operations; In high degree of Analyst coverage (Analyst1=1) group, the coefficient of M_DUM is not significant. Suppose 3a is established. 
Table 8. Analyst coverage, degree of diversified operations and stock price crash risk

\begin{tabular}{|c|c|c|c|c|}
\hline \multirow[t]{2}{*}{ VARIABLES } & \multicolumn{2}{|c|}{ NCSKEW $_{i, t+1}$} & \multicolumn{2}{|c|}{ DUVOL $_{i, t+1}$} \\
\hline & Analyst $1=1$ & Analyst $1=0$ & Analyst $1=1$ & Analyst $1=0$ \\
\hline \multirow[t]{2}{*}{ EI } & 0.0422 & $0.116^{* * *}$ & 0.0237 & $0.0616^{* * *}$ \\
\hline & $(0.0387)$ & $(0.0306)$ & $(0.0193)$ & $(0.0147)$ \\
\hline \multirow[t]{2}{*}{ NCSKEW $_{i, t}$} & $-0.119 * * *$ & $-0.0948 * * *$ & & \\
\hline & $(0.0111)$ & $(0.00990)$ & & \\
\hline \multirow[t]{2}{*}{$\operatorname{DUVOL}_{\mathrm{i}, \mathrm{t}}$} & & & $-0.120 * * *$ & $-0.0927 * * *$ \\
\hline & & & $(0.0108)$ & $(0.00980)$ \\
\hline \multirow[t]{2}{*}{ RET } & 0.318 & 33.33 & -12.11 & -5.252 \\
\hline & $(30.60)$ & (27.11) & (15.33) & (13.17) \\
\hline \multirow[t]{2}{*}{ SIGMA } & -2.391 & 0.257 & $-2.128 * *$ & $-1.545^{*}$ \\
\hline & $(1.827)$ & $(1.677)$ & $(0.911)$ & $(0.805)$ \\
\hline \multirow[t]{2}{*}{ OTURNOVER } & $-0.0385^{*}$ & $0.0355^{* *}$ & $-0.0209 * *$ & $0.0177 * *$ \\
\hline & $(0.0199)$ & $(0.0169)$ & $(0.0102)$ & $(0.00825)$ \\
\hline \multirow[t]{2}{*}{ BM } & $-0.506^{* * *}$ & $-0.290 * * *$ & $-0.255^{* * *}$ & $-0.172 * * *$ \\
\hline & $(0.0553)$ & $(0.0427)$ & $(0.0272)$ & $(0.0208)$ \\
\hline \multirow[t]{2}{*}{ LEVERAGE } & 0.131 & 0.0791 & 0.0345 & 0.0343 \\
\hline & $(0.0854)$ & $(0.0643)$ & $(0.0426)$ & $(0.0309)$ \\
\hline \multirow[t]{2}{*}{ ROA } & 0.335 & -0.0417 & 0.152 & -0.0455 \\
\hline & $(0.227)$ & $(0.142)$ & $(0.113)$ & $(0.0691)$ \\
\hline \multirow[t]{2}{*}{ SIZE } & $-0.0422 * * *$ & $-0.0320^{* *}$ & $-0.0144^{* *}$ & -0.00986 \\
\hline & $(0.0135)$ & $(0.0131)$ & $(0.00672)$ & $(0.00630)$ \\
\hline \multirow[t]{2}{*}{ Constant } & $0.980^{* * *}$ & $0.506^{*}$ & $0.339 * *$ & 0.151 \\
\hline & $(0.306)$ & $(0.283)$ & $(0.153)$ & $(0.136)$ \\
\hline Fixed Effect & + & + & + & + \\
\hline Observations & 10070 & 12411 & 10070 & 12411 \\
\hline R2 & 0.0275 & 0.0144 & 0.0278 & 0.0162 \\
\hline
\end{tabular}

Note. The $\mathrm{t}$ value in parentheses; *** means significant at $1 \%$ level, ** means significant at $5 \%$ level, * means significant at $10 \%$ level.

Table 8 shows the two group regression results of model (8) and model (9) when the grouping variable is the dummy variable Analyst1. In low degree of Analyst coverage (Analyst1=0) group, the coefficient of EI is 0.116 and 0.0616 , and it is significant at the level of 1\%, indicating that in companies with a high degree of Analyst coverage, stock price crash risk significantly increases when the degree of diversified operations deepens; In high degree of Analyst coverage (Analyst1=1) group, the coefficient of EI is not significant. Suppose $3 b$ is established.

From Tables 7 to 8, we can see that the values of M_DUM and EI are significantly positive and larger than the full sample results in the low level Analyst coverage group. This validates H3: Compared with companies with a high degree of Analyst coverage, the positive correlation between the diversification of companies with a low degree of Analyst coverage and stock price crash risk is more significant. At the same time, it also shows that analysts, as third-party institutions, do play a certain positive role in the operation of the enterprise.

\subsubsection{External Audit Quality, Diversification, and Stock Price Crash Risk}

In this section, we divide the full sample into two groups of high external audit quality and low external audit quality, based on the quality of external audit. First of all, this section takes the annual report of the company as an indicator to measure the quality of the company's external audit from whether the auditors are from the Big Four accounting firms (Wang et al., 2006). Specifically, Big4 is defined as a dummy variable of whether the company is audited by the "Big Four", and if the auditors of the annual report are from the "Big Four" accounting firms, it is divided into a high-quality external audit group. The value of Big4 is 1; otherwise, it is divided into the external audit low quality group, and the value of Big4 is 0 . 
Table 9 External audit quality, diversification strategy and stock price crash risk

\begin{tabular}{|c|c|c|c|c|}
\hline \multirow[t]{2}{*}{ VARIABLES } & \multicolumn{2}{|c|}{ NCSKEW $_{i, t+1}$} & \multicolumn{2}{|c|}{ DUVOL $_{i, t+1}$} \\
\hline & Big4=1 & Big4 $=0$ & Big4=1 & Big4 $=0$ \\
\hline \multirow[t]{2}{*}{ M_DUM } & 0.00399 & $0.0468 * * *$ & 0.0202 & $0.0258^{* * *}$ \\
\hline & $(0.0964)$ & $(0.0160)$ & $(0.0492)$ & $(0.00782)$ \\
\hline \multirow[t]{2}{*}{ NCSKEW $_{\mathrm{i}, \mathrm{t}}$} & $-0.101^{* * *}$ & $-0.0851 * * *$ & & \\
\hline & $(0.0325)$ & $(0.00730)$ & & \\
\hline \multirow[t]{2}{*}{ DUVOL $_{i, t}$} & & & $-0.114 * * *$ & $-0.0851 * * *$ \\
\hline & & & $(0.0316)$ & $(0.00712)$ \\
\hline \multirow[t]{2}{*}{ RET } & 6.169 & 27.68 & -15.45 & -3.475 \\
\hline & $(92.20)$ & (19.49) & $(47.42)$ & $(9.518)$ \\
\hline \multirow[t]{2}{*}{ SIGMA } & -3.831 & -0.293 & -3.391 & $-1.476^{* *}$ \\
\hline & (4.777) & $(1.185)$ & $(2.424)$ & $(0.574)$ \\
\hline \multirow[t]{2}{*}{ OTURNOVER } & $-0.226^{* * *}$ & 0.0181 & $-0.134 * * *$ & 0.00875 \\
\hline & $(0.0649)$ & $(0.0127)$ & $(0.0315)$ & $(0.00627)$ \\
\hline \multirow[t]{2}{*}{ BM } & $-0.583^{* * *}$ & $-0.363 * * *$ & $-0.326^{* * *}$ & $-0.198 * * *$ \\
\hline & $(0.146)$ & $(0.0336)$ & $(0.0667)$ & $(0.0164)$ \\
\hline \multirow[t]{2}{*}{ LEVERAGE } & 0.450 & $0.111^{* *}$ & 0.198 & $0.0436^{*}$ \\
\hline & $(0.293)$ & $(0.0513)$ & $(0.141)$ & $(0.0248)$ \\
\hline \multirow[t]{2}{*}{ ROA } & 0.907 & $0.202 *$ & $0.478^{*}$ & 0.0679 \\
\hline & $(0.563)$ & $(0.118)$ & $(0.262)$ & $(0.0583)$ \\
\hline \multirow[t]{2}{*}{ SIZE } & -0.0370 & $-0.0350 * * *$ & -0.00378 & $-0.0124 * * *$ \\
\hline & $(0.0516)$ & $(0.00886)$ & $(0.0275)$ & $(0.00422)$ \\
\hline \multirow[t]{2}{*}{ Constant } & 0.767 & $0.661 * * *$ & 0.0659 & $0.234 * *$ \\
\hline & (1.186) & $(0.196)$ & $(0.640)$ & $(0.0930)$ \\
\hline Fixed Effect & + & + & + & + \\
\hline Observations & 1279 & 21161 & 1279 & 21161 \\
\hline $\mathrm{R} 2$ & 0.0325 & 0.0152 & 0.0454 & 0.0165 \\
\hline
\end{tabular}

Note. The t value in parentheses; *** means significant at $1 \%$ level, ** means significant at $5 \%$ level, * means significant at $10 \%$ level.

Table 9 shows the two group regression results of model (6) and model (7) when the grouping variable is the dummy variable Big4. In the low quality external audit (Big4=0) group, the coefficient of M_DUM is 0.0468 and 0.0258 , and it is significant at the level of $1 \%$, which shows that in companies with a low quality external audit, stock price crash risk significantly increases when the enterprise changes from a specialized operations to a diversified operations; In the high quality external audit (Big4=1) group, the coefficient of M_DUM is not significant. This result verifies the hypothesis H4a. 
Table 10. External audit quality, degree of diversified operations and stock price crash risk

\begin{tabular}{|c|c|c|c|c|}
\hline \multirow[t]{2}{*}{ VARIABLES } & \multicolumn{2}{|c|}{ NCSKEW $_{i, t+1}$} & \multicolumn{2}{|c|}{ DUVOL $_{i, t+1}$} \\
\hline & Big4=1 & Big $4=0$ & Big4=1 & Big $4=0$ \\
\hline \multirow[t]{2}{*}{ EI } & 0.100 & $0.0759 * * *$ & 0.0711 & $0.0427 * * *$ \\
\hline & $(0.139)$ & $(0.0233)$ & $(0.0687)$ & $(0.0113)$ \\
\hline \multirow[t]{2}{*}{$\operatorname{NCSKEW}_{\mathrm{i}, \mathrm{t}}$} & $-0.102 * * *$ & $-0.0852 * * *$ & & \\
\hline & $(0.0324)$ & $(0.00729)$ & & \\
\hline \multirow[t]{2}{*}{ DUVOL $_{\mathrm{i}, \mathrm{t}}$} & & & $-0.115 * * *$ & $-0.0853 * * *$ \\
\hline & & & $(0.0315)$ & $(0.00712)$ \\
\hline \multirow[t]{2}{*}{ RET } & 5.785 & 28.33 & -15.91 & -3.099 \\
\hline & (92.46) & (19.49) & (47.49) & $(9.517)$ \\
\hline \multirow[t]{2}{*}{ SIGMA } & -3.901 & -0.261 & -3.453 & $-1.457^{* *}$ \\
\hline & $(4.782)$ & $(1.185)$ & $(2.420)$ & $(0.574)$ \\
\hline \multirow[t]{2}{*}{ OTURNOVER } & $-0.227 * * *$ & 0.0179 & $-0.134 * * *$ & 0.00864 \\
\hline & $(0.0653)$ & $(0.0127)$ & $(0.0317)$ & $(0.00627)$ \\
\hline \multirow[t]{2}{*}{$\mathrm{BM}$} & $-0.587 * * *$ & $-0.363 * * *$ & $-0.330 * * *$ & $-0.198 * * *$ \\
\hline & $(0.145)$ & $(0.0336)$ & $(0.0659)$ & $(0.0164)$ \\
\hline \multirow[t]{2}{*}{ LEVERAGE } & 0.460 & $0.111^{* *}$ & 0.201 & $0.0434 *$ \\
\hline & $(0.301)$ & $(0.0514)$ & $(0.145)$ & $(0.0248)$ \\
\hline \multirow[t]{2}{*}{ ROA } & $0.946^{*}$ & $0.202 *$ & $0.496^{*}$ & 0.0681 \\
\hline & $(0.559)$ & $(0.118)$ & $(0.260)$ & $(0.0582)$ \\
\hline \multirow[t]{2}{*}{ SIZE } & -0.0406 & $-0.0358 * * *$ & -0.00560 & $-0.0128 * * *$ \\
\hline & $(0.0511)$ & $(0.00889)$ & $(0.0274)$ & $(0.00423)$ \\
\hline \multirow[t]{2}{*}{ Constant } & 0.816 & $0.673 * * *$ & 0.0949 & $0.241^{* * *}$ \\
\hline & $(1.167)$ & $(0.196)$ & $(0.634)$ & $(0.0932)$ \\
\hline Fixed Effect & + & + & + & + \\
\hline Observations & 1279 & 21161 & 1279 & 21161 \\
\hline R2 & 0.0333 & 0.0154 & 0.0467 & 0.0167 \\
\hline
\end{tabular}

Note. The t value in parentheses; *** means significant at $1 \%$ level, $* *$ means significant at $5 \%$ level, * means significant at $10 \%$ level.

Table 10 shows the two group regression results of model (8) and model (9) when the grouping variable is the dummy variable Big4. In the low quality external audit (Big4=0) group, the coefficient of EI is 0.0759 and 0.0427 , and it is significant at the level of $1 \%$, which shows that in companies with a low quality external audit, stock price crash risk significantly increases when the degree of diversified operations deepens; In the high quality external audit (Big4=1) group, the coefficient of EI is not significant. This result verifies the hypothesis H4b.

As can be seen from Tables 9 and 10, in the firm with low audit quality, the values of M_DUM and EI are both significantly positive and greater than the full sample results. This result validates Hypothesis 4: Compared with companies with high external audit quality, in companies with low external audit quality, the positive correlation between diversification and stock price crash risk is more significant.

\subsection{Robustness Test and Additional Analysis}

\subsubsection{Alternative Measurement of Crash Risk}

For robustness check, we used another measure of crash risk, that is CRASH. CRASH: In a certain year, as long as the weekly unique returns of individual stocks meet the following equation at least once, the CRASH value is 1, otherwise, 0 .its calculation method is as follows:

$$
W_{i, t} \leq \operatorname{Average}\left(W_{i, t}\right)-3.09 \sigma_{i}^{3}
$$

Average $\left(W_{i, t}\right)$ is the annual mean value of weekly unique income of company $\mathrm{i} ; \sigma_{i}^{3}$ is the standard deviation of weekly unique income of company $\mathrm{i}$ in the current year [under the standard normal distribution, 3.09 standard deviations correspond to a probability interval of about $0.1 \%$.]. 
Table 11. Diversification and stock price crash risk

\begin{tabular}{|c|c|c|c|c|}
\hline \multirow[t]{2}{*}{ VARIABLES } & (1) & (2) & (3) & \multirow{2}{*}{ (4) } \\
\hline & CRASH $_{\mathrm{i}, \mathrm{t}+1}$ & CRASH $_{\mathrm{i}, \mathrm{t}+1}$ & CRASH $_{i, t+1}$ & \\
\hline \multirow[t]{2}{*}{ M_DUM } & 0.0297 & $0.148^{* *}$ & & \\
\hline & $(0.0440)$ & $(0.0706)$ & & \\
\hline \multirow[t]{2}{*}{ EI } & & & 0.0419 & $0.310^{* * *}$ \\
\hline & & & $(0.0575)$ & $(0.103)$ \\
\hline \multirow[t]{2}{*}{ CRASH $_{\mathrm{i}, \mathrm{t}}$} & $0.155^{* *}$ & $-0.692 * * *$ & $0.155^{* *}$ & $-0.695 * * *$ \\
\hline & $(0.0664)$ & $(0.0714)$ & $(0.0664)$ & $(0.0714)$ \\
\hline \multirow[t]{2}{*}{ RET } & -99.95 & $-169.7^{*}$ & -99.64 & $-166.2 *$ \\
\hline & $(89.37)$ & $(95.01)$ & $(89.40)$ & $(95.03)$ \\
\hline \multirow[t]{2}{*}{ SIGMA } & $-17.93 * * *$ & $-24.85^{* * *}$ & $-17.92 * * *$ & $-24.66 * * *$ \\
\hline & $(5.211)$ & $(5.693)$ & $(5.211)$ & $(5.695)$ \\
\hline \multirow[t]{2}{*}{ OTURNOVER } & 0.0253 & $0.108 *$ & 0.0253 & $0.108^{*}$ \\
\hline & $(0.0534)$ & $(0.0615)$ & $(0.0534)$ & $(0.0616)$ \\
\hline \multirow[t]{2}{*}{ BM } & $-1.242 * * *$ & $-1.736^{* * *}$ & $-1.242 * * *$ & $-1.738 * * *$ \\
\hline & $(0.113)$ & $(0.159)$ & $(0.113)$ & $(0.159)$ \\
\hline \multirow[t]{2}{*}{ LEVERAGE } & $0.353^{* * *}$ & 0.258 & $0.354 * * *$ & 0.258 \\
\hline & $(0.116)$ & $(0.210)$ & $(0.116)$ & $(0.210)$ \\
\hline \multirow[t]{2}{*}{ ROA } & $-0.917^{* *}$ & -0.507 & $-0.916^{* *}$ & -0.491 \\
\hline & $(0.410)$ & $(0.519)$ & $(0.410)$ & $(0.519)$ \\
\hline \multirow[t]{2}{*}{ SIZE } & $0.0426^{* *}$ & $0.163^{* * *}$ & $0.0422 * *$ & $0.159^{* * *}$ \\
\hline & $(0.0205)$ & $(0.0353)$ & $(0.0205)$ & $(0.0353)$ \\
\hline \multirow[t]{2}{*}{ Constant } & $-1.810^{* * *}$ & - & $-1.802 * * *$ & - \\
\hline & $(0.466)$ & - & $(0.466)$ & - \\
\hline Fixed Effect & - & + & - & + \\
\hline Observations & 22481 & 15017 & 22481 & 15017 \\
\hline
\end{tabular}

Note. The $\mathrm{t}$ value in parentheses; *** means significant at the $1 \%$ level, ** means significant at the $5 \%$ level, * means significant at the $10 \%$ level.

From Table 11, we can see that both the horizontal and vertical effects of Diversification strategy are positive, but it is not significant in terms of horizontal effects. the vertical effect is the same as above. In other words, the impact of the diversification model as a operating status on crash risk is not significant. However, if an enterprise changes from a specialized operations to diversified operations, or the degree of diversified operation deepens, the company's crash risk will increase accordingly, which is consistent with the above research.

\subsubsection{Endogenous Treatment}

With reference to the practice in the existing literature (Jiang, et al., 2015). As dependent variable, the estimated period of stock price crash risk was extended to two years. In this way, not only can we further examine the long-term effects of diversification on stock price crash risk in the future; more importantly, this can further overcome the endogenous problems caused by diversification and stock price crash risk. 
Table 12. Diversification and stock price crash risk

\begin{tabular}{|c|c|c|c|c|}
\hline \multirow[t]{2}{*}{ VARIABLES } & (1) & (2) & (3) & (4) \\
\hline & $\operatorname{NCSKEW}_{\mathrm{i}, \mathrm{t}+2}$ & NCSKEW $_{i, t+2}$ & DUVOL $_{i, t+2}$ & DUVOL $_{\mathrm{i}, \mathrm{t}+2}$ \\
\hline \multirow[t]{2}{*}{ M_DUM } & & $0.0692 * * *$ & & $0.0352 * * *$ \\
\hline & & $(0.0170)$ & & $(0.00829)$ \\
\hline \multirow[t]{2}{*}{ EI } & $0.0946 * * *$ & & $0.0501 * * *$ & \\
\hline & $(0.0253)$ & & $(0.0126)$ & \\
\hline \multirow[t]{2}{*}{$\operatorname{NCSKEW}_{\mathrm{i}, \mathrm{t}}$} & $-0.0978 * * *$ & $-0.0978 * * *$ & & \\
\hline & $(0.00795)$ & $(0.00795)$ & & \\
\hline \multirow[t]{2}{*}{ DUVOL $_{i, t}$} & & & $-0.105^{* * *}$ & $-0.105^{* * *}$ \\
\hline & & & $(0.00789)$ & $(0.00789)$ \\
\hline \multirow[t]{2}{*}{ RET } & $-48.63 * *$ & $-49.76^{* *}$ & $-26.07 * * *$ & $-26.67 * * *$ \\
\hline & $(19.72)$ & $(19.70)$ & $(9.825)$ & $(9.819)$ \\
\hline \multirow[t]{2}{*}{ SIGMA } & $-3.948 * * *$ & $-4.006^{* * *}$ & $-2.069 * * *$ & $-2.100 * * *$ \\
\hline & $(1.257)$ & $(1.256)$ & $(0.620)$ & $(0.619)$ \\
\hline \multirow[t]{2}{*}{ OTURNOVER } & $0.200 * * *$ & $0.200 * * *$ & $0.119 * * *$ & $0.119 * * *$ \\
\hline & $(0.0163)$ & $(0.0163)$ & $(0.00816)$ & $(0.00817)$ \\
\hline \multirow[t]{2}{*}{$\mathrm{BM}$} & $0.299 * * *$ & $0.298 * * *$ & $0.155^{* * *}$ & $0.155^{* * *}$ \\
\hline & $(0.0368)$ & $(0.0369)$ & $(0.0185)$ & $(0.0185)$ \\
\hline \multirow[t]{2}{*}{ LEVERAGE } & $0.179 * * *$ & $0.180 * * *$ & $0.0864 * * *$ & $0.0872 * * *$ \\
\hline & $(0.0542)$ & $(0.0542)$ & $(0.0269)$ & $(0.0269)$ \\
\hline \multirow[t]{2}{*}{ ROA } & $0.404 * * *$ & $0.408 * * *$ & $0.137 * *$ & $0.138 * *$ \\
\hline & $(0.126)$ & $(0.126)$ & $(0.0639)$ & $(0.0639)$ \\
\hline \multirow[t]{2}{*}{ SIZE } & $-0.119 * * *$ & $-0.119 * * *$ & $-0.0631 * * *$ & $-0.0628 * * *$ \\
\hline & $(0.00981)$ & $(0.00979)$ & $(0.00485)$ & $(0.00483)$ \\
\hline \multirow[t]{2}{*}{ Constant } & $2.205 * * *$ & $2.194 * * *$ & $1.136^{* * *}$ & $1.129 * * *$ \\
\hline & $(0.223)$ & $(0.223)$ & $(0.109)$ & $(0.109)$ \\
\hline Fixed Effect & + & + & + & + \\
\hline Observations & 17111 & 17111 & 17111 & 17111 \\
\hline $\mathrm{R} 2$ & 0.0337 & 0.0338 & 0.0415 & 0.0415 \\
\hline
\end{tabular}

Note. The t value in parentheses; *** means significant at $1 \%$ level, ** means significant at $5 \%$ level, * means significant at $10 \%$ level.

The results are shown in Table 12. It can be seen that after expanding the forecast window to two years, the coefficient of M_DUM is 0.0692 and 0.0352 , the coefficient of EI is 0.0946 and 0.0501 , which is still significantly positive at the $1 \%$ level, confirming that diversification will increase stock price crash risk. It also shows that the impact of diversification on stock price crash risk is long-term and continuous.

\section{Conclusions}

The stability and good operation of the stock market are necessary conditions to ensure the stable, healthy and development of the country's economy, and to protect the interests of investors from damage. Since 2008, stock price crash have often appeared in the public eye in China's stock market. Therefore, studying the influencing factors of stock price crash risk is of great significance to prevent and reduce the stock price crash risk.

This paper summarizes the reasons of stock price crash risk by combing existing research results at home and abroad. Under the framework of information asymmetry theory and principal-agent theory, this paper analyzes the impact of diversification strategy and the degree of diversified operations on stock price crash risk. The results of the study are as follows: First, our results suggest that diversification strategy increases Chinese listed company's stock price crash risk. Furthermore, we find that stock price crash risk is significant increased. When companies change from specialized operations to diversified operations or the degree of diversified operations increases. Considering the special existence of China's market ownership structure system, our results are stronger for non-SOEs, but not significant for SOEs. Finally, we find that strong external monitoring mitigates the impact of diversification strategy on crash risk. More specifically, we find that Big Four auditors and high analyst coverage help lessen the impact.

This article studies the impact of diversification strategy and the degree of diversified operations on the stock price crash risk, and provides the following suggestions: (1) Choose a strategy that is suitable for the company itself, and moderately diversify. In the process of diversification strategy and diversified operations expansion, 
listed companies in China should not blindly develop their business and expand their scale. Instead, they should attach importance to the development of their main businesses, cultivate their core capabilities, and lay the foundation for their long-term sustainable survival and development. At the same time, make a diversification strategy carefully, and in the process of diversification, adjust the corporate structure, increase the intensity of information disclosure, and enhance the liquidity of information;(2) When investing, investors can use diversification as a reference index for risk identification and analysis, in order to avoid stock price crash risk;(3) Market regulators should further strengthen the information disclosure of listed companies, especially those with a higher degree of diversified operations, and urge the diversified firm to improve their corporate governance structure, enhance resource liquidity, improve the allocation efficiency of social resources, so as to reduce the positive effect of diversification on stock price crash risk.

\section{Acknowledgements}

Supported by Guangdong Natural Science Foundation, No. 100021.

\section{References}

Amy, P., Hutton, A. J., Marcus, H. T. (2009). Opaque financial reports, R2, and crash risk. Journal of Financial Economics, 94(1), 67-86. https://doi.org/10.1016/j.jfineco.2008.10.003

Ansoff, H. I. (1957). Strategies for Diversification. Harvard Business Review, 35(5), 113-124.

Benmelech, E., Kandel, E., \& Veronesi, P. (2007). Stock-Based compensation and CEO (Dis)Incentives. The Quarterly Journal of Economics, 125(4), 1769-1820. https://doi.org/10.2139/ssrn.1108362

Bradley, D., Clarke, J., Lee, S., \& Ornthanalai, C. (2014). Are analysts' recommendations informative? Intraday evidence on the impact of time stamp delays. Journal of Finance, 69, 645-673. https://doi.org/10.2139/ssrn.1571920

Cai, W. X., \& Zeng, C. (2010). The impact of corporate diversification on the attention of securities analysts. Finance and Accounting, 13(4), 125-133. https://doi.org/10.3969/j.issn.1008-3448.2010.04.015

Callen, J. L., \& Fang, X. (2017). Crash Risk and the Auditor-Client Relationship. Contemporary Accounting Research, 34, 1715-1750. https://doi.org/10.1111/1911-3846.12311

Callen, J. L., Fang, X. H. (2012). Religion and Stock Price Crash Risk. Journal of Financial \& Quantitative Analysis, 50(1-2), 169-195. https://doi.org/10.1017/S0022109015000046

Callen, J., \& Fang, X. H. (2015). Short Interest and Stock Price Crash Risk. Journal of Banking and Finance, 60, 181-194. https://doi.org/10.1016/j.jbankfin.2015.08.009

Cang, Y. T. (2008). Research on company characteristics, follow-up of financial analysts and monitoring effectiveness. Shanghai: Shanghai University of Finance and Economics. Retrieved from http://www.wanfangdata.com.cn/details/detail.do?_type=degree\&id=Y1494647

Dai, D. M., \& Deng, F. (2008). Research on the Relationship between Information Asymmetry and Diversified Discounts: Evidence from Listed Companies in Shanghai Stock Market, China. Journal of Finance and Economics, 4, 82-92. https://doi.org/10.16538/j.cnki.jfe.2008.04.009

Gong, G. M., \& Huang, S. Y. (2014). Diversified operations, media functions and quality of accounting information-empirical evidence from listed companies in China. Journal of Audit \& Economics, 29(4), 50-60.

Retrieved

from https://kns.cnki.net/KCMS/detail/detail.aspx?dbcode $=$ CJFQ \&dbname=CJFD2014\&filename $=$ SJYJ2014040 07\&v=MTI4ODdmWnVSckZpbmxVYnJJTmlmU1pMRzRIOVhNcTQ5Rlk0UjhlWDFMdXhZUzdEaDFU M3FUcldNMUZyQ1VSN3E=

Greene, W. H. (1993). Econometric Analysis. New York, NY: Macmillan.

Harry, M. (1952). Portfolio selection. The Journal of Finance, 7, 77-91.

$\mathrm{Hu}, \mathrm{Z}$. H. (2018). Deepening the reform of state-owned firm with the help of the principle of neutrality in competition. People's Forum, 36, 84-86. https://doi.org/10.3969/j.issn.1004-3381.2018.36.031

Jebran, K., Chen, S., \& Zhu, D. H. (2019). Board informal hierarchy and stock price crash risk: theory and evidence from China. Corporate Governance: An International Review, 27(5), 341-357. https://doi.org/10.1111/corg.12282

Jeong-Bon, K., \& Zhang, L. D. (2012). Accounting Conservatism and Stock Price Crash Risk: Firm-Level Evidence. Contemporary Accounting Research, 33(1), 412-441. https://doi.org/10.2139/ssrn.1521345 
Jeong-Bon, K., Li, Y. H., \& Zhang, L. D. (2011a). Corporate tax avoidance and stock price crash risk: Firm-Level analysis. Journal of Financial Economics, 100(3), 639-662. https://doi.org/10.1016/j.jfineco.2010.07.007

Jeong-Bon, K., Li, Y. H., \& Zhang, L. D. (2011b). CFOs versus CEOs: Equity incentives and crashes.. Journal of Financial Economics, 101, 713-730. https://doi.org/10.1016/j.jfineco.2011.03.013

Jeong-Bon, K., Wang, Z., \& Zhang, L. D. (2016). CEO Overconfidence and Stock Price Crash Risk. Contemporary Accounting Research, 33(4), 1720-1749. https://doi.org/10.1111/1911-3846.12217

Jiang, X. Y., \& Xu, N. X. (2015). Over-investment of firm and stock price crash risk. Financial Research, 8, 141-158. Retrieved from http://kns.cnki.net/kcms/detail/detail.aspx?FileName=JRYJ201508010\&DbName=CJFQ2015

Jiang, X. Y., \& Yi, Z. H. (2013). Auditor Industry Specialization and Stock Price Crash Risk. China Accounting Review, 11(2), 134-149. Retrieved from http://www.wanfangdata.com.cn/details/detail.do?_type=perio\&id=zgkjpl201302002

Jin, L., \& Myers, S. C. (2006). R2 around the World: New Theory and New Tests. Journal of Financial Economics, 61(2), 257-292. https://doi.org/10.1016/j.jfineco.2004.11.003

Li, S. N. (2011). Research on the Relationship between Bank Loans and Investment Behaviors of Listed Companies in China-Analysis Based on the Adjustment Effect of the Nature of Actual Controller. Journal of Management, 8(3), 464-470. https://doi.org/10.3969/j.issn.1672-884X.2011.03.021

Liu, Y. J., Sun, Y., \& Liu, N. Q. (2003). Ultimate ownership structure Theory, Shareholding Structure and Corporate Performance. Economic Research, 4, 51-62. Retrieved from http://www.wanfangdata.com.cn/details/detail.do?_type=perio\&id=jjyj200304006

Lu, Z. F., \& Zhang, H. L. (2010). Ownership arrangement, rent-seeking space and cash distribution: empirical evidence from China's A-share market. Management World, 5, 150-158. Retrieved from http://www.wanfangdata.com.cn/details/detail.do?_type=perio\&id=glsj201005016

Lubatkin, M., \& Chatterjee, S. (1994). Extending Modern Portfolio Theory into the Domain of Corporate Diversification: Does It Apply? The Academy of Management Journal, 37(1), 109-136. https://doi.org/10.5465/256772

Luo, J. H., Du, X. Q. (2014). Media reports, institutional environment and the risk of stock market crash. Accounting Research, 9, 53-59. https://doi.org/10.3969/j.issn.1003-2886.2014.09.007

Mark, H. L. (2009). Analysts' incentives to produce industry-level versus firm-specific information. Journal of Financial and Quantitative Analysis, 46(3), 757-784. https://doi.org/10.2139/ssrn.680000

Pan, Y., Dai, Y. Y., \& Lin, C. Q. (2011). Information opacity, Analyst coverage and stock price crash risk. Journal of Financial Research, 9, 138-151. Retrieved from http://www.wanfangdata.com.cn/details/detail.do? type=perio\&id=jryj201109011

Quan, X. F., Wu, S. N., \& Yin, H. Y. (2015). Corporate Social Responsibility and Stock Price Crash Risk: Self-interest Tool or Value Strategy? Economic Research, 50(11), 49-64. Retrieved from http://www.wanfangdata.com.cn/details/detail.do?_type=perio\&id=jjyj201511004

Su, D. W. (2005). Diversification and Enterprise Value: An Empirical Analysis of Diversification Premium of Listed Companies in China. Quarterly Journal of Economics, 4, 136-159. Retrieved from https://kns.cnki.net/kcms/detail/detail.aspx?filename=BDGF200510002008\&dbcode $=$ CPFD\&dbname $=$ CPF D2014\&v=

Tang, S., \& Sun, Z. (2014). Political connection, executive compensation and future business performance of firm. Management World, 5, 93-105. Retrieved from http://www.wanfangdata.com.cn/details/detail.do?_type=perio\&id=glsj201405008

Wang, Y. Y., \& Chen, H. W. (2006). Audit Quality and Transparency of Accounting Information. Accounting Research, 4, 9-15. https://doi.org/10.3969/j.issn.1003-2886.2006.04.002

Wang, Z., Fu, G. Q., Huang, D. Y., \& Wang, J. F. (2014). Research on the Relationship between "Political Promotion" and "On-the-job Consumption" of CEOs of State-owned firm. Management World, 5, 157-171. Retrieved from http://www.wanfangdata.com.cn/details/detail.do?_type=perio\&id=glsj201405013

Wu, Z. C., \& Li, X. L. (2015). Insider selling, information environment and stock price crash. Accounting 
Research, 6, 48-55. https://doi.org/10.3969/j.issn.1003-2886.2015.06.007

Xu, N. X., Yu, S. Y., \& Yi, Z. H. (2013). Herd behavior of institutional investors and the risk of stock market crash. Management World, 3, 31-43. Retrieved from http://www.wanfangdata.com.cn/details/detail.do?_type=perio\&id=glsj201307004

Xu, N., Li, X., Yuan, Q., \& Chan, K. C. (2014). Excess perks and stock price crash risk: evidence from China. Corporate Finance, 25, 419-434. https://doi.org/10.1016/j.jcorpfin.2014.01.006

Yang, R. L., Wang, Y., \& Nie, H. H. (2013). Promotional Mechanism of "Associate Officials": Evidence from Chinese Central firm, Management World, 3, 23-33. Retrieved from http://www.wanfangdata.com.cn/details/detail.do?_type=perio\&id=glsj201303004

Zhang, G. M., \& Li, Y. Y. (2012). Research on the Impact of Business Diversification on Enterprise Performance Based on Agency Theory.The Theory and Practice of Finance and Economics, 33(3), 98-102. https://doi.org/10.3969/j.issn.1003-7217.2012.03.020

Zhang, J. S., \& Zeng, Y. M. (2010). Diversified operation, earnings management and performance divergence of listed companies. Finance and Accounting Research, 25(4), 58-64. Retrieved from http://www.wanfangdata.com.cn/details/detail.do?_type=perio\&id=sjyjjyj201004009

Zheng, Z. G., Li, D. X., Xu, R., Lin, R. T., \& Zhao, X. J. (2012). Political Promotion and Image Engineering of State-owned Enterprise Executives: A Case Study Based on Company A in N Province. Management World, 10, 146-156. Retrieved from http://www.wanfangdata.com.cn/details/detail.do?_type=perio\&id=glsj201210012

\section{Copyrights}

Copyright for this article is retained by the author(s), with first publication rights granted to the journal.

This is an open-access article distributed under the terms and conditions of the Creative Commons Attribution license (http://creativecommons.org/licenses/by/4.0/). 